\title{
The Effect of Metabolic Regulation on Microvascular Permeability to Small and Large Molecules in Short-Term Juvenile Diabetics
}

\author{
H.-H. Parving, I. Noer, T. Deckert, P.-E. Evrin, S. L. Nielsen, J. Lyngsøe, C. E. Mogensen, M. Rørth, \\ P. Aa. Svendsen, J. Trap-Jensen, and N. A. Lassen \\ Dept. of Clinical Physiology and Dept. of Medicine T, Bispebjerg Hospital, Dept. of Clinical Physiology, Frederiksberg Hospital, \\ Steno Memorial Hospital, Copenhagen, Department of Medicine A, Rigshospitalet, Univ. of Copenhagen and Second Univ. Clinic \\ of Internal Medicine, Kommunehospitalet, Århus, Denmark; Institute of Medical Chemistry, Univ. of Uppsala, Sweden
}

Summary. The microvascular permeability to small and large molecules was studied during good and poor metabolic regulation in ten short duration juvenile diabetics. The following variables were measured; daily urinary albumin and $\beta_{2}$-microglobulin-excretion rates, whole body transcapillary escape rate of albumin (TER), glomerular filtration rate (GFR), capillary filtration coefficient (CFC), and capillary diffusion capacity (CDC). The urinary albumin and $\beta_{2}$-microglobulin concentration were measured by sensitive radioimmunoassays; TER was determined from the initial disappearance of intravenously injected ${ }^{125}$ I-labelled human serum albumin; GFR was measured by single shot ${ }^{51} \mathrm{Cr}$-EDTA clearance; CFC was measured on the forearm by straingauge plethysmography and CDC for ${ }^{51} \mathrm{Cr}$-EDTA was determined in the hyperaemic anterior tibial muscle by the local clearance technique. All the above mentioned variables, except CDC, were significantly increased during poor metabolic regulation, indicating a functional microangiopathy. The mechanisms of these alterations appear to be increased filtration pressure in the microcirculation and/or increased porosity of the microvasculature. The findings of increased microvascular albumin passage are compatible with the hypothesis that the organic - histologically demonstrated - diabetic microangiopathy is a long-term effect of periods of increased extravasation of plasma proteins, with subsequent protein deposition in the microvascular wall, i. e. the concept of plasmatic vasculosis.

Key words: Diabetic microangiopathy, early diabetes, influence of metabolic regulation, microvascular permeability of small and large molecules.
Vascular lesions constitute a cardinal feature of the long-term diabetic syndrome. The most characteristic vascular lesion is the microangiopathy which involves arterioles, venules and, particularly, the capillaries all over the body. The initial lesion consists of an increased thickness of the capillary basement membrane, demonstrable in the kidney after only one and a half years of diabetes, by use of quantitative electronmicroscopy [37]. This lesion corresponds to the subendothelial PAS-positive deposits demonstrated in the wall of the microvessels by light microscopy. Spiro et al. [31, 32] suggested that the thickened capillary basement membrane and the PAS-positive deposits could result from an overproduction of basement membrane material. Another hypothesis is that increased extravasation of plasma proteins and their deposition in the wall of the microvasculature is involved in the morphogenesis of diabetic microangiopathy. This is the concept of plasmatic vasculosis originally advocated by Lendrum [18].

The aim of the present study was to determine the microvascular protein escape in short-term juvenile diabetics during good and poor metabolic regulation. This was done in order to evaluate the hypothesis of plasmatic vasculosis.

\section{Material and Methods}

Ten insulin dependent juvenile diabetics ( 6 females and 4 males), aged $17-35$ years (mean 25 years), all of whom had been fully informed of the nature of the study before giving their consent, were investigated. Three of the diabetics were newly diagnosed, six of the patients had been diabetic less than 1.5 years and one patient for 4 years. Their clinical and laboratory data are shown in Table 1 . 
Table 1. Clinical data of ten short-term juvenile diabetics

\begin{tabular}{|c|c|c|c|c|c|c|c|c|c|c|c|c|}
\hline \multirow[t]{2}{*}{$\begin{array}{l}\text { Subj. } \\
\text { No }\end{array}$} & \multirow[t]{2}{*}{$\begin{array}{l}\text { Age } \\
\text { (years) }\end{array}$} & \multirow[t]{2}{*}{$\begin{array}{l}\text { Duration } \\
\text { of diabetes } \\
\text { (month) }\end{array}$} & \multicolumn{2}{|c|}{$\begin{array}{l}\text { Plasma } \\
\text { glucose } \\
(\mathrm{mmol} / 1)\end{array}$} & \multicolumn{2}{|c|}{$\begin{array}{l}\text { Venous } \\
\mathrm{pH}\end{array}$} & \multicolumn{2}{|c|}{$\begin{array}{l}\text { Standard } \\
\text { bicarbonate } \\
(\mathrm{mmol} / 1)\end{array}$} & \multicolumn{2}{|c|}{$\begin{array}{l}\text { Blood } \\
\text { pressure } \\
(\mathrm{mm} / \mathrm{Hg})\end{array}$} & \multicolumn{2}{|c|}{$\begin{array}{l}\text { Plasma } \\
\text { volume } \\
\text { (1) }\end{array}$} \\
\hline & & & I & II & I & II & I & II & I & II & I & II \\
\hline 1 & 34 & 0.3 & 4.0 & 11.0 & 7.38 & 7.28 & 24.2 & 18.8 & $110 / 74$ & $110 / 74$ & 3.3 & 2.7 \\
\hline 2 & 24 & 17 & 8.0 & 12.9 & 7.37 & 7.37 & 25.7 & 25.6 & $112 / 74$ & $120 / 70$ & 4.1 & 3.6 \\
\hline 3 & 34 & 12 & 5.3 & 10.6 & 7.36 & 7.29 & 25.6 & 21.0 & $102 / 75$ & $104 / 68$ & 2.8 & 2.5 \\
\hline 4 & 18 & 10 & 3.7 & 20.2 & 7.37 & 7.32 & 26.3 & 21.5 & $102 / 64$ & $102 / 68$ & 3.2 & 2.7 \\
\hline 5 & 21 & 6 & 7.0 & 20.8 & 7.35 & 7.32 & 27.0 & 22.4 & $106 / 68$ & $105 / 68$ & 2.8 & 2.4 \\
\hline 6 & 32 & 0.3 & 7.8 & 11.5 & 7.36 & 7.27 & 22.5 & 16.8 & $134 / 82$ & $148 / 94$ & 4.3 & 2.8 \\
\hline 7 & 29 & 7 & 4.5 & 10.5 & 7.37 & 7.37 & 27.1 & 25.5 & $101 / 64$ & $100 / 66$ & 2.8 & 2.6 \\
\hline 8 & 19 & 12 & 8.5 & 18.8 & 7.33 & 7.31 & 21.7 & 21.5 & $125 / 73$ & $116 / 70$ & 2.5 & 2.2 \\
\hline 9 & 24 & 0.3 & 10.5 & 13.7 & 7.39 & 7.35 & 26.5 & 26.2 & $108 / 68$ & $116 / 70$ & 3.1 & 2.8 \\
\hline 10 & 18 & 40 & 4.1 & 14.1 & 7.36 & 7.36 & 29.0 & 26.2 & $98 / 54$ & $112 / 68$ & 3.2 & 3.0 \\
\hline$p$ value & & & \multicolumn{2}{|c|}{$<0.005$} & \multicolumn{2}{|c|}{$<0.05$} & \multicolumn{2}{|c|}{$<0.005$} & \multicolumn{2}{|l|}{ N.S. } & \multicolumn{2}{|c|}{$<0.005$} \\
\hline
\end{tabular}

The patients were studied in the morning after at least 12 fasting and half an hours rest in the supine position. The patients were studied in both good and poor metabolic regulation, using identical experimental procedures. The latter state was obtained by reducing or stopping insulin therapy for some days prior to the investigation. The interval between the two investigations was one week in seven of the patients and three to five weeks in the other three. All variables, except those of the urine, were measured on the same day between $7.30 \mathrm{a} . \mathrm{m}$. and $1 \mathrm{p}$. $\mathrm{m}$. They are listed below according to the time of the day on which they were carried out.

The transcapillary escape rate of albumin (TER), defined as the fraction of intravascular mass of albumin that passes to the extravascular space per unit time, was determined from the disappearance of intravenously injected ${ }^{125}$ I-labelled human serum albumin (code MIAK, Institute for Atomic Energy, Kjeller, Norway) during the first $60 \mathrm{~min}$ after the injection. We have previously described this procedure and the theoretical basis for the calculation of TER in detail $[24,25]$.

Glomerular filtration rate (GFR) was measured after a single intravenous injection of ${ }^{51} \mathrm{Cr}$-EDTA by studying the plasma disappearance for four hours, as described elsewhere [4].

Resting blood flows were recorded with a strain gauge plethysmograph placed on the proximal third of the forearm using the technique described by Dahn et al. [5]. Ten consecutive readings were taken with a pressure in the occlusion cuff of $50 \mathrm{~mm} \mathrm{Hg}$ and with exclusion of hand blood flow. Capillary filtration coefficient (CFC) was thereafter measured twice accord- ing to Krogh et al. [17], with a strain-gauge plethysmograph placed on the distal third of the forearm, using the slope between 5 and 10 minutes of venous stasis at a pressure of $50 \mathrm{~mm} \mathrm{Hg}$, with no correction for the transmission of pressure to the exchange vessels.

Capillary diffusion capacity (CDC) was measured in the anterior tibial muscle during reactive hyperaemia after simultaneous intramuscular injection of ${ }^{133}$ Xenon and ${ }^{51} \mathrm{Cr}$-EDTA as described previously by us [34].

The in vivo oxygen affinity of red cells expressed as $\mathrm{P}_{50}$, i. e. the oxygen tension giving $50 \%$ oxyhaemoglobin saturation at the prevailing $\mathrm{pH}$ and $\mathrm{pCO}_{2}$, was calculated from the measured venous $\mathrm{PO}_{2}$ and oxyhaemoglobin saturation by means of the Hill equation, as described previously [29, 30]. The intraerythrocytic concentration of 2,3-diphosphoglycerate was measured enzymatically [23]. Serum osmolality was measured with a wide range osmometer (Advanced Instruments Inc., USA). Plasma immunoreactive growth hormone [12] was measured six times in each patient on samples taken at half hour intervals during the morning of the investigation. Plasma glucose, $\mathrm{pH}$ and standard bicarbonate were measured 4 times between $7.30 \mathrm{a}$. m. and $1 \mathrm{p}$. m., using conventional laboratory techniques. Keto-acidosis is defined, in this study, as the presence of ketone bodies in the urine and an intra-individual reduction of $\mathrm{pH} \geqslant 0.05$ unit and of standard bicarbonate $\geq 4.0 \mathrm{mmol}$.

In each patient urine was collected for at least two 24 hours periods during the good and the poor metabolic state. Only urine with no signs of bacteriuria was included in the investigation. Urine speci- 
mens were stored deep-frozen and centrifuged before analysis. Urinary albumin concentration was measured with a radioimmunoassay, using a single-antibody technique [22]. Urinary $\beta_{2}$-microglobulin concentration was also measured by a radioimmunoassay [10]. Wilcoxon's non-parametric test for paired comparison was used for statistical analysis.

\section{Results}

The clinical data and the state of metabolic regulation of the patients during the two investigations are shown in the Table.

Figure 1 shows the urinary albumin and $\beta_{2}$-microglobulin excretion rates. Even when the two patients (no 1 and 6) with the most severe keto-acidosis and with the highest albumin ( 27 and $300 \mathrm{mg} / 24 \mathrm{~h}$ ) and $\beta_{2}$-microglobulin excretion rates (1620 and 3260 $\mu \mathrm{g} / 24 \mathrm{~h}$ ) are omitted, the albumin excretion rate is still significantly increased during poor control (mean 16.0 (SD 5.7) $\mathrm{mg} / 24 \mathrm{~h}$ ); $+125 \%, p<0.01$. Likewise a significant increase in $\beta_{2}$-microglobulin excretion rate was found during poor (mean 123 (SD 66) $\mu \mathrm{g} / 24 \mathrm{~h}$ ) compared to good metabolic regulation (75 (SD 42) $\mu \mathrm{g} / 24 \mathrm{~h}) ;+64 \%, p<0,05$. The albumin $/ \beta_{2}$-microglobulin ratio was increased during poor (mean 174) compared with good metabolic regulation (mean $132) ;+32 \%$, through the difference was not statistically significant. The daily urine volume remained about the same during good (mean 2608 (SD $813 \mathrm{ml}$ ) and poor metabolic regulation (mean 2625 (SD $806 \mathrm{ml}$ ).

Figure 2 demonstrates that the glomerular filtration rate was increased in all patients investigated during the poor metabolic state (mean 122 (SD 15) $\mathrm{ml} / \mathrm{min} / 1.73 \mathrm{~m}^{2}$ ), compared with the good (mean 101 (SD 7) $\mathrm{ml} / \mathrm{min} / 1.73 \mathrm{~m}^{2}$ ) $p<0.005$.

Figure 3 shows that transcapillary escape rate of albumin was increased in eight, unchanged in one and reduced in one patient during poor (mean 6.9 (SD $0.5) \% / \mathrm{h}$ ) compared to good metabolic regulation (mean 5.7 (SD 0.9) \%/h); + 21\%, $p<0.01$.

Figure 4 shows the resting forearm blood flow, capillary filtration coefficient and capillary diffusion capacity. The forearm blood flow was increased in all patients during poor metabolic state (mean 3.47 (SD 1.38) $\mathrm{ml} / 100 \mathrm{ml} / \mathrm{min}$ ) compared to the good state (mean 2.21 (SD 0.54$) \mathrm{ml} / 100 \mathrm{ml} / \mathrm{min}$ ); $+57 \%$, $p<0.001$. The capillary filtration coefficient increased in eight and decreased in two patients during the poor metabolic condition (mean 6.38 (SD 2.95) $\mathrm{ml} \times 10^{3} / 100 \mathrm{ml} / \mathrm{min} / \mathrm{mm} \mathrm{Hg}$ ) compared with the good condition (mean $4.81(\mathrm{SD} 2.37) \mathrm{ml} \times 10^{3} /$ $100 \mathrm{ml} / \mathrm{min} / \mathrm{mm} \mathrm{Hg}) ;+33 \%, p<0.05$. The capillary
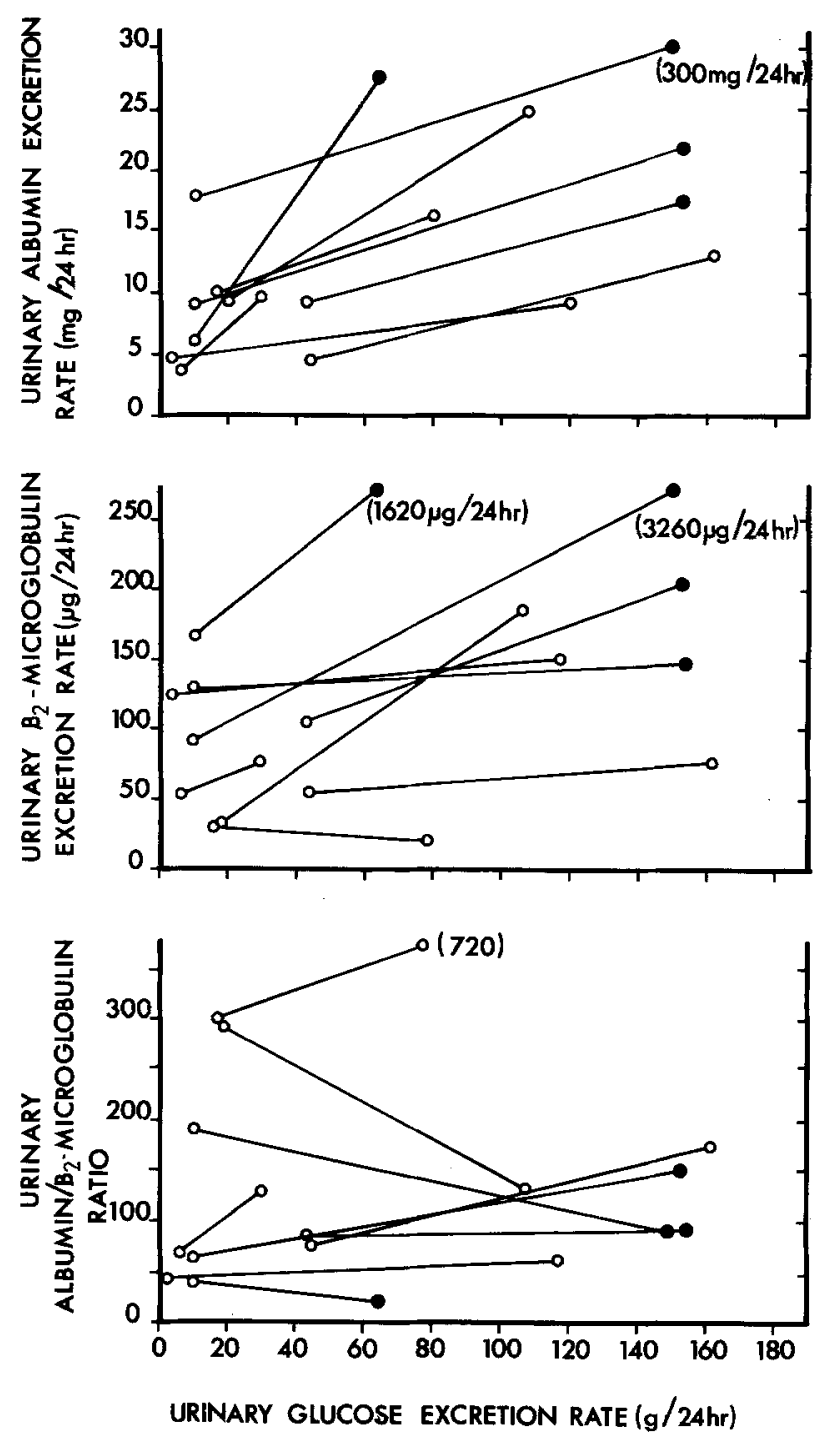

Fig. 1. The individual mean values of the daily urinary excretion rates of albumin, $\beta_{2}$-microglobulin and glucose in short-term juvenile diabetics during good and poor metabolic regulation. Ketonuric $(\bullet)$ and non-ketonuric $(\circ)$ patients. All variables represent an average of at least two determinations in each patient

diffusion capacity remained about the same in the two metabolic conditions.

The plasma immunoreactive growth hormone, expressed as a mean of six determinations in each patient, was not significantly changed from the good (mean of individual mean values $5.8(\mathrm{SD} 0.33) \mathrm{ng} / \mathrm{ml}$ ) to the poor metabolic state (mean of individual mean values $6.4(\mathrm{SD} 0.44) \mathrm{ng} / \mathrm{ml}$ ). The in vivo oxygen affinity of red cells was about the same in the good (mean 27.0 (SD 1.0) $\mathrm{mm} \mathrm{Hg}$ ) compared with the poor metabolic state (mean 26.7 (SD 1.4) $\mathrm{mm} \mathrm{Hg}$ ). A significant reduction took place in the intraerythrocytic concentration of 2,3-diphosphoglycerate in the poor (1.26 (SD 0.28) moles/mole haemoglobin tet- 


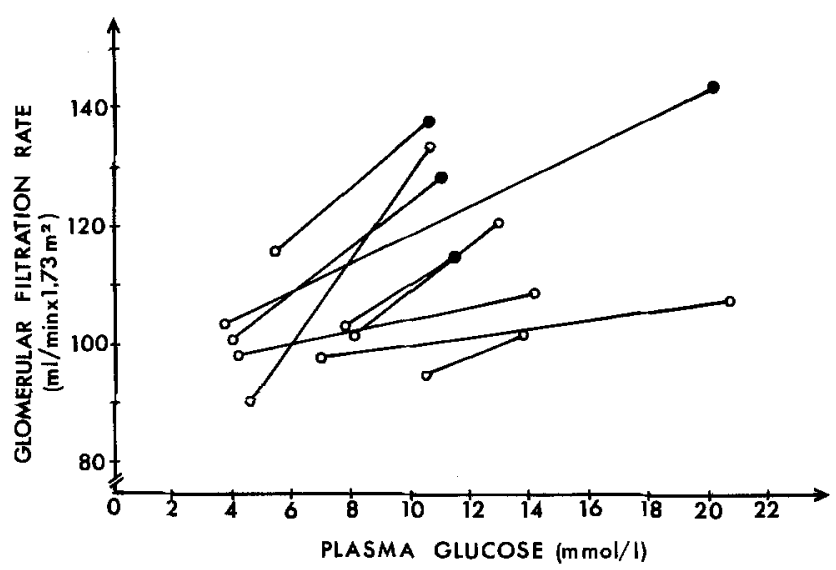

Fig. 2. Glomerular filtration rate in short-term juvenile diabetics during good and poor metabolic regulation. Ketoacidotic (v) and non-ketoacidotic $(0)$ patients. Plasma glucose values are mean of four determinations in each patient

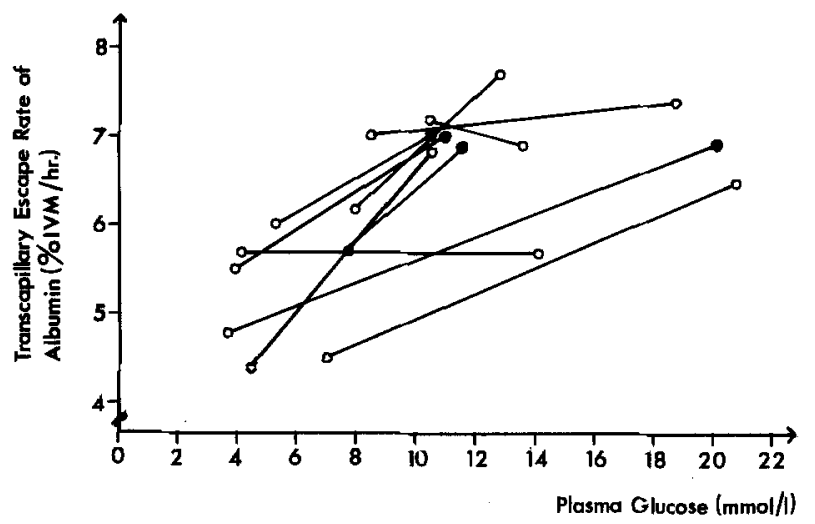

Fig. 3. Transcapillary escape rate of albumin in short-term juvenile diabetics during good and poor metabolic regulation. Keto-acidotic $(\bullet)$ and non-keto-acidotic (O) patients. Plasma glucose values are mean of four determinations in each patient

ramer) compared with the good metabolic state ( 1.43 (SD 0.23) moles/mol haemoglobin tetramer); $-12 \%$, $p<0.05$. Serum osmolality remained about the same during good (mean 281 (SD 4) $\mathrm{m} \mathrm{osmol} / \mathrm{kg}$ ) and poor metabolic regulation (283 (SD 6) $\mathrm{m} \mathrm{osmol} / \mathrm{kg}$ ).

\section{Discussion}

Several investigators have measured the urinary albumin and total protein excretion rate in order to evaluate the permeability of the glomerular capillaries in early diabetes mellitus. In connection with a large diabetes survey Keen et al. $[15,16]$ found a positive correlation between urinary albumin excretion rate and blood glucose concentration in patients suffering from borderline and early diabetes (mainly adult type). The patients were given $50 \mathrm{~g}$ glucose by mouth
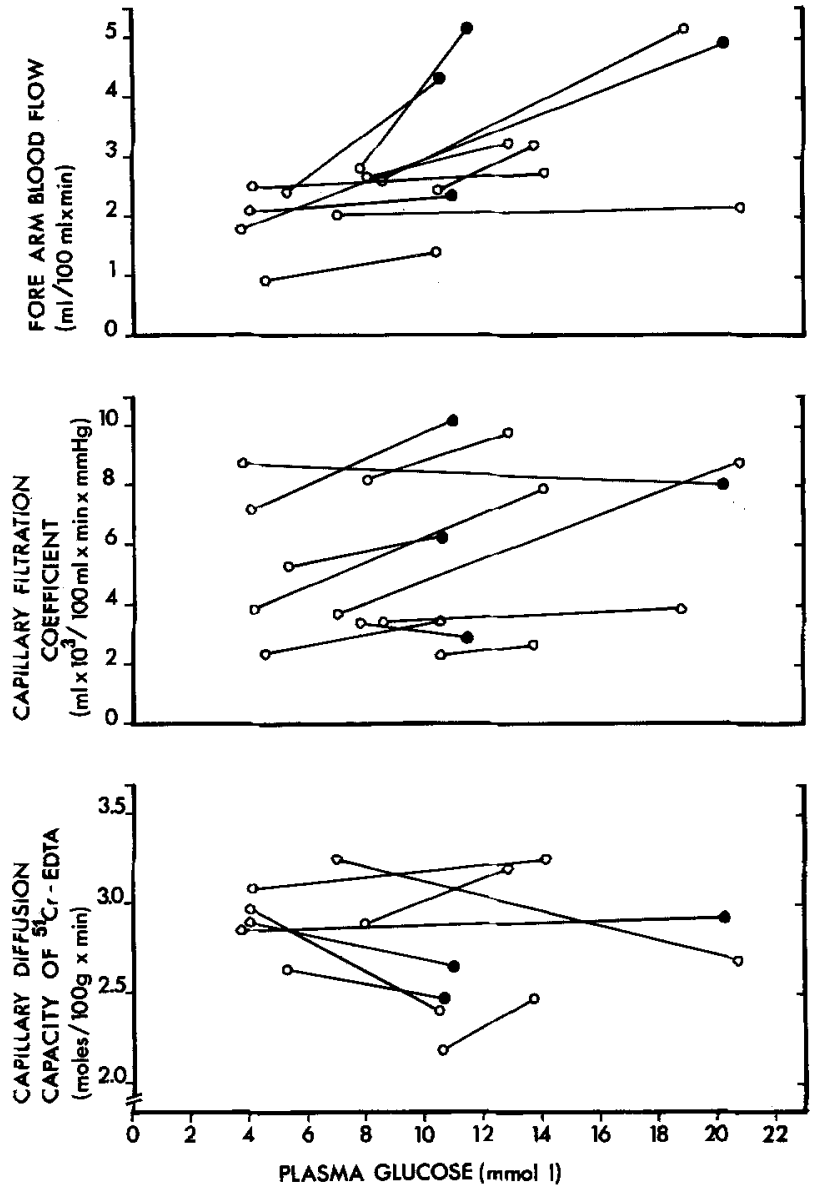

Fig. 4. Forearm blood flow, capillary filtration coefficient in subcutaneous tissue and capillary diffusion capacity in skeletal muscle in short-term juvenile diabetics during good and poor metabolic regulation. Keto-acidotic $(0)$ and non-ketoacidotic $(\bullet)$ patients. Plasma glucose values are mean of four determinations in each patient

just before start of the 2 hours urine sampling period. Albumin was determined by a sensitive radioimmunoassay. In a later study by the same group [3], it was demonstrated that the urinary albumin excretion rate was abnormally elevated in juvenile and adult onset diabetics with a recognized duration of the disease of less than 3 years. Glucose was not given in that study. Unfortunately, data on metabolic regulation are not available from the study, except that the diuresis was 2.7 times greater in the diabetics compared to the normals, which might indicate some degree of dysregulation. Mogensen [20] measured the urinary albumin excretion before and during insulin treatment in 5 newly diagnosed juvenile diabetics, by use of a sensitive radioimmunoassay. The albumin excretion rate was significantly increased before insulin therapy and it normalized during insulin treatment. Furthermore, he demonstrated a normal urinary albu- 
min excretion rate in short-term juvenile diabetics in good metabolic regulation. Evidence suggesting an increased transglomerular passage of plasma proteins in untreated and treated newly diagnosed juvenile diabetics has been obtained by some investigators demonstrating an increased urinary protein excretion rate even at the onset of the disease [7, 14]. The Lowry method and a Kjeldahl technique was used for protein determination in these studies.

Except for Mogensen [20], all the above mentioned investigators have interpreted the finding of increased urinary protein excretion as evidence of a functional abnormality of the glomerular membrane, viz. increased permeability. However, increased urinary protein excretion can be caused either by an increase in transglomerular passage of protein, and/or by a reduction in tubular reabsorption of protein. Glomerular and tubular proteinuria can be distinguished by simultaneously measuring the urinary $\beta_{2}$-microglobulin and albumin excretion rates, as demonstrated by Petersen et al. [27].

In the present study the urinary $\beta_{2}$-microglobulin excretion rate was increased during poor metabolic control, indicating a reduced tubular reabsorption for protein. The same result has recently been obtained by Hanssen et al. [13]. The urinary albumin excretion rate was even more increased during poor metabolic control as reflected by the finding of an increased albumin/ $\beta_{2}$-microglobulin ratio in 6 out of the 9 so investigated patients. These findings suggest that the increased urinary albumin excretion rate is dominated by an increased transglomerular passage of albumin, while the contribution from tubular dysfunction is small. The finding by Mogensen [19] of a highly significant increase in the renal dextran (m. w. 20000 to 50000 ) clearances before and, to a lesser extent, during insulin treatment of early juvenile diabetics, is in agreement with the above mentioned conclusion, since dextrans are neither excreted nor reabsorbed by the tubular cells in any measurable amount $[1,2]$.

The present finding of an increased transcapillary escape rate of albumin during poor metabolic regulation further demonstrate that an increased extravasation of albumin occurs in the microvasculature of the extra-renal organs - the transglomerular fraction of the overall albumin extravasation rate constitutes maximally a few percent. The present finding of an increased capillary filtration coefficient in the subcutaneous tissue of the forearm during poor metabolic control further emphasizes the leakyness of the microvasculature of the body. It is a well established fact that the glomerular filtration rate, as demonstrated in the present study, is increased during poor metabolic control and can be normalized during effective insulin treatment (for review see Mogensen [21]). All the above mentioned observations constitute strong evidence in favour of the concept advocated by Ditzel, viz. that a functional microangiopathy precedes the anatomical changes [6].

The mechanisms involved in the increased extravasation of small and large molecules through the microvasculature can either be an increase in the permeability-surface area product (PS product of Renkin [28]) and/or an increased hydrostatic pressure in the microcirculation. There is evidence from several organs suggesting increased filtration pressure in the microcirculation during poor metabolic control, viz. increased blood flow in peripheral tissues [11] and an increased filtration fraction in the kidney (for review see Mogensen [21]). In this connection it should be mentioned that moderate arterial hypertension causes an increased transcapillary escape rate and transglomerular passage of albumin, probably due to an elevated filtration pressure in the microcirculation $[24,26]$.

Concerning the capillary surface area, data are only available from the kidney. Østerby et al. [37] demonstrated that the glomeruli were enlarged, the number of cells normal and the intraluminal area of the glomerular capillaries increased in early juvenile diabetics. This finding suggests that an increased total capillary surface area is available in the glomerular capillaries.

It is important to stress that morphological alterations, viz. increased thickness of the glomerular basement membrane cannot be the cause of the increased transglomerular protein passage in the present study (except subject no. 10), since this thickening is first demonstrable after one and a half years duration of the diabetes (for review see Østerby [37]).

The trigger mechanism of the previously mentioned alterations in the microcirculation in early juvenile diabetics during poor metabolic control is not known, but several factors have been suggested, e. g. hyperosmolality [35], hypoxia [8], and growth hormone [21]. However, these variables were not significantly changed in the present study.

Despite the large amount of information concerning the diabetic microangiopathy, the morphogenesis of this lesion is still unknown. Several investigations have clearly demonstrated that many different plasma proteins are present in the deposits e. g. fibrin, IgG, IgM and albumin (for review see Dustin [9], Lendrum [18], Thomsen [33] and Westberg [36]). The present finding of an increased microvascular protein passage at the onset of the diabetes, and thus before the thickening of the basement membrane can be demonstrated, suggests that increased plasma protein extravasation is an initial and perhaps decisive event in the morphogenesis of diabetic microangiopathy. In 
making this suggestion the slight to moderate metabolic dysregulation provoked in our patients should be emphasized. Periods of such dysregulation undoubtedly often occur spontaneously in most "well treated" diabetics. If, as suggested above, extravasation of plasma proteins, with subsequent deposition into the vascular wall, is involved in the development of microangiopathy as a complication to diabetes, our results support the case for an effective treatment of diabetes.

\section{References}

1. Arturson, G., Wallenius, G.: The renal clearance of dextran of different molecular sizes in normal humans. Scand. J. clin. Lab. Invest. 16, 81-86 (1964)

2. Arturson, G., Granath, K., Grotte, G.: Intravascular persistence and renal clearance of dextran of different molecular sizes in normal children. Arch. Dis. Childh. 41, 168-171 (1966)

3. Balodimos, M. C., Chlouverakis, C., Gleason, R. E., Jarrett, R. J., Kahn, C. B., Keen, H., Soeldner, J. S.: Urinary albumin excretion in the offspring of conjugal diabetes. Lancet 1971 II, 239-242

4. Bröchner-Mortensen, H., Giese, H., Rossing, N.: Renal inulin clearance versus total plasma clearance of ${ }^{51} \mathrm{Cr}$-EDTA. Scand. J. clin. Lab. Invest. 23, 301-305 (1969)

5. Dahn, I., Hallböök, T.: Simultaneous blood flow measurements by water and strain gauge plethysmography. Scand. J. clin. Lab. Invest. 25, 419-428 (1970)

6. Ditzel, J.: Functional microangiopathy in diabetes mellitus. Diabetes 17, 388-397 (1968)

7. Ditzel, J., Junker, K.: Abnormal glomerular filtration rate, renal plasma flow, and renal protein excretion in recent and short-term diabetics. Brit. med. J. 1972 II, 13-19

8. Ditzel, J.: Impaired oxygen release caused by alterations of the metabolism in the erythrocytes in diabetes. Lancet $1972 \mathrm{I}$, 721-723

9. Dustin, P.: Arteriolar hyalinosis. Int. Rev. exp. Path. 1, 73-138 (1962)

10. Evrin, P.-E., Peterson, P. A., Wide, L., Berggaard, J.: Radioimmunoassay of $\beta_{2}$-microglobulin in human biological fluids. Scand. J. clin. Lab. Invest. 28, 439-444 (1971)

11. Gundersen, J. J. G.: Peripheral blood flow and metabolic control in juvenile diabetes. Diabetologia 10, 225-331 (1974)

12. Hanssen, K. F.: Radioimmunoassay of growth hormone in human plasma. Acta endocr. 71, 649-664 (1972)

13. Hanssen, K. F.: Urinary growth hormone. Oslo: Universitetsforlagets Tryknings Sentral 1975

14. Hemmingsen, L., Høiby, N., Kragh-Sørensen, P.: Protein and LDH-isoenzyme pattern of the urine from patients with diabetes mellitus determined by disc-electrophoresis. Diabetologia 6, 512-518 (1970)

15. Keen, H., Chlouverakis, C.: Urinary albumin excretion and diabetes mellitus. Lancet 1964 II, 1155-1156

16. Keen, H., Chlouverakis, C., Fuller, J., Jarrett, R. J.: The concomitants of raised blood sugar: Studies in newly-detected hyperglycaemics. II. Urinary albumin extretion, blood pressure and their relation to blood sugar levels. Guy's Hosp. Rep. 118, 247-254 (1969)

17. Krogh, A., Landis, E. M., Turner, A. H.: The movement of fluid through the human capillary wall in relation to venous pressure and to the colloid osmotic pressure of the blood. J. clin. Invest. 11, 63-95 (1932)

18. Lendrum, A. C.: The hypertensive diabetic kidney as a model of so-called collagen diseases. Canad. med. Ass. J. 88, 442-452 (1963)

19. Mogensen, C. E.: Kidney function and glomerular permeability to macromolecules in early juvenile diabetes. Scand. J. clin. Lab. Invest. 28, 79-90 (1971)

20. Mogensen, C. E.: Urinary albumin excretion in early and longterm juvenile diabetes. Scand. J. clin. Lab. Invest. 28, 183-193 (1971)

21. Mogensen, C. E.: Kidney function and glomerular permeability to macromolecules in juvenile diabetes. Copenhagen: Costers 1972

22. Miles, D. W., Mogensen, C. E., Gundersen, H. J. G.: Radioimmunoassay for urinary albumin using a single antibody. Scand. J. clin. Lab. Invest. 26, 5-11 (1970)

23. Nygaard, S. F., Rørth, M.: An enzymatic assay of 2,3 diphosphoglycerate in blood. Scand. J. clin. Lab. Invest. 24, 399-404 (1969)

24. Parving, H.-H., Gyntelberg, F.: Transcapillary escape rate of albumin and plasma volume in essential hypertension. Circulat. Res. 32, 643-651 (1973)

25. Parving, H.-H., Rasmussen, S. M.: Transcapillary escape rate of albumin and plasma volume in short- and long-term juvenile diabetics. Scand. J. clin. Lab. Invest. 32, 81-87 (1973)

26. Parving, H.-H., Jensen, H. Æ., Mogensen, C. E., Evrin, P.-E.: Increased urinary albumin-excretion rate in benign essential hypertension. Lancet 1974 I, 1190-1192

27. Peterson, P. A., Evrin, P.-E., Berggaard, I.: Differentiation of glomerular, tubular, and normal proteinuria: Determinations of urinary excretion of $\beta_{2}$-microglobulin, albumin, and total protein. J. clin. Invest. 48, 1189-1198 (1969)

28. Renkin, E. M.: Transport of large molecules across capillary walls. Physiologist 7, 13-28 (1964)

29. Rørth, M., Parving, H.-H., Munkgaard, S.: Red-cell oxygen affinity and 2,3 diphosphoglycerate in diabetes. Lancet 1972 I, 1179

30. Rørth, M.: Hypoxia, red cell oxygen affinity and erythropoitin production. Clinics Haematol. 3, 595-607 (1974)

31. Spiro, R. G.: Glycoproteins: Their biochemistry, biology and role in human disease. New Engl. J. Med. 281, 1043-1056 (1969)

32. Spiro, R. G., Spiro, M. J.: Effect of diabetes on biosynthesis of the renal glomerular basement membrane. Diabetes 20, 641 (1971)

33. Thomsen, $\AA$. Chr.: The kidney in diabetes mellitus. Copenhagen: Munksgaard 1965

34. Trap-Jensen, J., Alpert, J. C., Garcia del Rio, H., Lassen, N. A.: Capillary diffusion capacity for sodium in skeletal muscle in long-term juvenile diabetes mellitus. Acta med. scand., Suppl. 476, 135-146 (1967)

35. Trap-Jensen, J.: Skeletal muscle capillary permeability in diabetic microangiopathy. In: Microcirculatory approaches to current therapeutic problems (eds. J. Ditzel, H. Lewis), pp. 137-141. Basel: Karger Publ. 1971

36. Westberg, N. G.: Human glomerular basement membrane. Göteborg: Gotab. 1973

37. Østerby, R.: Early phases in the development of diabetic glomerulopathy. Århus: Århus Stiftsbogtrykkeri 1975

Received: August 13, 1975, and in revised form: February 11, 1976

Dr. H.-H. Parving

Dept. of Clinical Physiology

Bispebjerg Hospital

Bispebjerg Bakke 23

DK-2400 Copenhagen N. V.

Denmark 